\title{
Risk management of the alternative power engineering
}

\author{
L. Rodina ${ }^{1, *}$ \\ ${ }^{1}$ Omsk State University named by F.M. Dostoevsky, Omsk, Russia
}

\begin{abstract}
The article summarizes the experience of risk neutralization arising due to the power generation from the alternative sources - solar, wind, hydraulic power engineering on the basis of ebbs and flows, the use of biomass power plants, etc. At the same time, the tool for blitz diagnostics of risks of the alternative power engineering is proposed in order to substantiate the economic feasibility of investments. The results of the risk assessment application of alternative power engineering reduce the level of information uncertainty relating to the transition to new energy sources or diversification of energy supply.
\end{abstract}

\section{Introduction}

High energy dependence of the modern material production, increasing human needs for energy, limited fuel mineral resources of the planet, uneven distribution of the fuel raw materials in the subsoil, asymmetrical location of fuel resources and the major energy consumers, the issue of the greenhouse effect [1] represent only part of the problems, the solution of which is implied by the means of alternative power engineering. At the same time, the alternative power engineering types are still considered as an additional source of electrical energy [2].

In this regard, a special role is given to the renewable energy sources [3, 4]: solar radiation, wind power, current strength of water objects, including the ebbs and flows, organic reactions based on the biomasses, atmospheric electricity, etc. Mankind is finally thinking about the fact that the traditional energy based on the hydrocarbon raw materials does not provide a long-term guarantee of economic stability, since the gas, oil and coal deposits are exhausted quickly enough, and their renewal lasts for about two million years.

\section{Results}

At the same time, there are a great many new options for the production and use of electricity that, however, does not exclude its limitation in the energy problems solution. Consequently, in the conditions of information uncertainty, it is important to reduce the level of risks and optimally substantiate the managerial decision in relation to the transition to alternative power engineering, for example, for the investment purposes [5, 6]. Having identified and summarized the main risks of alternative power engineering, it is important to make systematization in order to aggregate the cumulative risk assessment [7] of each option.

\subsection{Risks of solar radiation use}

The solar (helio) power engineering in the world energy system takes up a significant place due to a variety of reasons: the conditional inexhaustibility of the energy source, absence of the greenhouse effect during the power generation, the noiselessness and environmental friendliness of solar power plant elements, etc. At the same time, a number of significant shortcomings in the use of solar energy can be identified (Table 1) that, however, can be perceived as an initiating factor for problem neutralization and solution.

Thus, it is possible to conclude that the development of solar energy industry is not related to the critical risks, and the solar panels can be used in the areas with extensive open spaces to generate additional energy at an acceptable level of economic, social, technological, resource efficiency [9].

\subsection{Risks of wind power use}

The wind energy sector is considered in modern conditions as an active option for additional energy supply [10] for a number of reasons: renewability and conditional inexhaustibility of wind energy, wastelessness and ecological cleanness of power generation, conditionally low costs for the station operation and maintenance, minor land allocation for the turbines, etc. The wind power plants do not confront other structures (production, infrastructure, residential ones, etc.), organically combining a unified land use.

The possibility of distributed placement of wind generators with various dimensions allows using the turbines of not only large industrial, but also small "home" options. It is also possible to mount the wind turbines on other structures, including movable ones. We will summarize the key risks of using wind energy (Table 2) in terms of reduction of the information

\footnotetext{
* Corresponding author: campoce6e@gmail.com
} 
Table 1. Risks of solar radiation use in the energy industry and neutralization measures.

\begin{tabular}{|l|l|}
\hline Risks of solar radiation use & \multicolumn{1}{c|}{ Risk neutralization measures (or reactions) } \\
\hline $\begin{array}{l}\text { 1. Instability of the power } \\
\text { source }\end{array}$ & $\begin{array}{l}\text { The ability to offer the mobile designs, providing a response to the level of illumination at } \\
\text { any given moment. It is also proposed to upgrade the battery to the sensitivity level (even in } \\
\text { the low light conditions, for example, with the clouded sky, 50\% of solar radiation still } \\
\text { reaches the surface). }\end{array}$ \\
\hline $\begin{array}{l}\text { 2. The need for land } \\
\text { allocation for the heliostation }\end{array}$ & $\begin{array}{l}\text { In the conditions of limited valuable land areas, a "top floor" scheme is proposed for the } \\
\text { heliostation structures. In this case, the separate land allocation is not required, since the } \\
\text { photocells will be constructed above the existing facilities, for example, on the roofs of the } \\
\text { large-scale industrial buildings. }\end{array}$ \\
\hline $\begin{array}{l}\text { 3. Significant capital } \\
\text { investments in the } \\
\text { construction the } \\
\text { heliostation the }\end{array}$ & $\begin{array}{l}\text { The economic practice proves that the increased production volume potentially leads to the } \\
\text { lower costs. The active expansion of possibilities of the solar energy use can be perceived as } \\
\text { a factor in reducing both variable and direct costs. In addition, we are talking about the } \\
\text { relatively quick payback costs (for example, according to the German experience [8], the } \\
\text { payback period of a medium power heliostation is about 2 years). }\end{array}$ \\
\hline $\begin{array}{l}\text { 4. Climatic and natural risks } \\
\text { for the solar panels }\end{array}$ & $\begin{array}{l}\text { The fragility of panel design is the points to ponder by the technologists. In addition, the } \\
\text { negative impact of natural factors on epy solar panels can be minimized, ensuring their } \\
\text { mobility not only to respond to the illumination level, but also to the direction of rain, hail } \\
\text { shower, threatening to the structures. The design conception is also provided in relation to } \\
\text { the protective coatings, including the mobile ones, for a period of negative impact. }\end{array}$ \\
\hline
\end{tabular}

uncertainty when making decisions about transferring to the alternative power engineering supply.

Thus, the wind energy sector certainly has a chance to take rightful place in the range of alternative power engineering types. It is actively proved by the practice of the German "home energy industry" with a compensation return scheme for surplus electricity to the general network.

\subsection{Risks of tidal force use}

The hydraulic power engineering [12] on the basis of ebbs and flows is considered for limited use as an alternative power engineering typical for the areas with a marine and oceanic coastline.

The predictability and reliability of tidal energy is one of the key benefits of this renewable form of energy. Ecological cleanliness of the power generation,

Table 2. Risks of wind power use in the energy industry and neutralization measures.

\begin{tabular}{|c|c|}
\hline Risks of wind power use & Risk neutralization measures (or reactions) \\
\hline $\begin{array}{l}\text { 1. Instability of the power } \\
\text { source }\end{array}$ & $\begin{array}{l}\text { The "background" wind is available in almost any territory. The situation of complete and long- } \\
\text { lasting calm air is a rare phenomenon in the field. Therefore, the offer of highly sensitive wind } \\
\text { turbines can be considered as a solution to this problem. It is also possible to offer the wind } \\
\text { turbines with telescopic mechanisms for changes in the turbine height. }\end{array}$ \\
\hline $\begin{array}{l}\text { 2. High noise level during } \\
\text { the wind turbine operation }\end{array}$ & $\begin{array}{l}\text { The distributed placement of wind turbines, considering the location of residential areas, will } \\
\text { reduce the risk of noise impact on the residents. } \\
\text { The turbine location at a distance of } 150-200 \mathrm{~m} \text { from the premises already allows to neutralize } \\
\text { the risk. }\end{array}$ \\
\hline $\begin{array}{l}\text { 3. High costs for the power } \\
\text { transmission lines due to the } \\
\text { large distance of wind } \\
\text { generators from the energy } \\
\text { consumers }\end{array}$ & $\begin{array}{l}\text { If the wind turbines are installed in the areas with high standard wind velocities (for example, in } \\
\text { the open ocean, in deserts, etc.), then the closest consumers of the generated electricity can be } \\
\text { rather far away, and there is a need to build the expensive power transmission lines. } \\
\text { However, firstly, such a scheme is not typical, and secondly, the payback period of capital } \\
\text { expenditures on the line is about one year, especially if the power transmission lines are laid } \\
\text { simultaneously with the fiber-optic cable of the global networks. }\end{array}$ \\
\hline $\begin{array}{l}\text { 4. Climatic and natural risks } \\
\text { for the wind turbines }\end{array}$ & $\begin{array}{l}\text { Irresistible natural phenomena and forces surely threaten the wind turbines, but no more than } \\
\text { other property facilities. In addition, the climatic risks [11] (for example, hurricanes, storms, } \\
\text { thunderstorms) in most areas are not the typical natural phenomens with a short recurrence } \\
\text { interval, therefore, the probability of critical turbine destruction is hardly considered high. } \\
\text { As a supplement, it is possible to offer the design conception to strengthen the structure of a } \\
\text { large wind station with a height of over } 60 \mathrm{~m} \text { to minimize the negative effects of the elements. } \\
\text { The additional functionality for the wind generator is also offered to collect lightning energy (a } \\
\text { lightning conductor with the possibility of accumulating powerful energy bundle). }\end{array}$ \\
\hline $\begin{array}{l}\text { 5. Threat to the animal } \\
\text { world (mainly birds) due to } \\
\text { the wind generator } \\
\text { operation }\end{array}$ & $\begin{array}{l}\text { The average wind power at which the wind generator generates electricity is } 4.5 \mathrm{~m} / \mathrm{s} \text { that implies } \\
\text { the same rotation rate of the turbine blades. This rate is not critical for members of the animal } \\
\text { world, so they will have the possibility to react to an obstacle in the form of a wind generator, } \\
\text { even at a height of } 30 \text { to } 60 \mathrm{~m} \text {. }\end{array}$ \\
\hline
\end{tabular}


Table 3. Risks of tidal force use in the energy industry and neutralization measures.

\begin{tabular}{|l|l|}
\hline \multicolumn{1}{|c|}{ Risks of tidal force use } & \multicolumn{1}{c|}{ Risk neutralization measures (or reactions) } \\
\hline $\begin{array}{l}\text { 1. Significant capital } \\
\text { investments in the hydroelectric } \\
\text { power plant }\end{array}$ & $\begin{array}{l}\text { Having considered the low operating costs, it is quite possible to take such a risk, } \\
\text { focusing on the payback period of the station that is about 3 years. }\end{array}$ \\
\hline $\begin{array}{l}\text { 2. Negative impact on marine } \\
\text { flora and fauna }\end{array}$ & $\begin{array}{l}\text { There are possible options for the buffer reas that limit the access of marine inhabitants } \\
\text { to the turbine blades with the threat to their lives. }\end{array}$ \\
\hline $\begin{array}{l}\text { 3. Changes in the specifications } \\
\text { of a water object in the case of } \\
\text { the tidal station dam }\end{array}$ & $\begin{array}{l}\text { This risk is typical for the stations with dams that is not a prerequisite for operation. } \\
\text { However, even if the construction implies a dam, the changes in specifications are not } \\
\text { considered as a critical risk. The dam area is much less than the water area of the entire } \\
\text { water object (sea, ocean) to make the impact significant. }\end{array}$ \\
\hline 4. Local flood risk & $\begin{array}{l}\text { This potential threat is likely in the case of an erroneous station design and is impossible } \\
\text { with the correct calculation of the tank filling level in the case of ebbs and flows in } \\
\text { accordance with the sea level during such phases. }\end{array}$ \\
\hline
\end{tabular}

conventional simplicity and low costs of the plant operation, the ability to use the turbine structures for additional construction (for example, for the roads), conflict-free marine shipping (the turbine is located at depth), etc. are the feasible arguments in favor of hydraulic power engineering on the basis of ebbs and flows.

However, this type of energy is not hassle-free and have some potential risks (Table 3 ).

Thus, the specific nature of hydraulic power engineering on the basis of ebbs and flows is such that some of the risks have to be taken without tangible possibility of its neutralization.

\subsection{Risks of biomass use in the energy industry}

The biomass power plants [13] with the active release of methane are considered to be an unconventional type of energy. This energy source is considered in the context of renewability, continuity, stability of the station operation, the possibility of dispersing energy resources and reducing the disaster risks, influence of the human factor in the energy sector, etc.

The vulnerability of this energy will be considered in terms of exposure to the risks of biomass use in the power generation (Table 4).

Thus, the power generation based on the biomass can be available even to the households using the methaneoperated generators while observing the safety rules for such biogas storage. However, methane is produced not only during the composting process, but it is also an associated gas during the exploitation of hydrocarbon deposits.

Consequently, the offer of technologies for the profitable methane collection as an associated gas is also aimed at the development of alternative power engineering based on the waste-free production principles.

\section{Discussion}

Having considered the various alternative power engineering options, it can be assumed that their key risks are comparable [14]. Therefore, they can be generalized and evaluated. In this regard, the tool for blitz diagnostics of alternative power engineering is proposed that makes it possible to justify the managerial decision to use one or another option (Table 5).

This example includes 5 types of risks that are typical for all considered alternative power engineering options to different extents. At the same time, the specific gravity of risks indicates their importance for the decision maker - the higher the significance, the higher

Table 4. Risks of the biomass power plant use in the energy industry and neutralization measures.

\begin{tabular}{|l|l|}
\hline \multicolumn{1}{|c|}{$\begin{array}{c}\text { Risks of biomass use in the } \\
\text { energy industry }\end{array}$} & Risk neutralization measures (or reactions) \\
\hline 1. Environmental risks & $\begin{array}{l}\text { When comparing to the hydrocarbon fuels, the biomass burning provides significantly } \\
\text { less environmental pollution. However, it is impossible to completely avoid the negative } \\
\text { impact due to the nitrogen oxides, carbon and dust. At the same time, special attention } \\
\text { should be paid to the filtration and purification system during the biomass burning. The } \\
\text { regulatory mechanisms are also required (for example, tax mechanisms) to stimulate } \\
\text { measures to ensure the ecological cleanness of power generation. }\end{array}$ \\
\hline $\begin{array}{l}\text { 2. The risk of uncontrolled fuel } \\
\text { removal from the biomass } \\
\text { (plants) }\end{array}$ & $\begin{array}{l}\text { The conflict between the agricultural and technical use of plants is possible. In this } \\
\text { regard, the regulatory mechanism for the use of biomaterials (for example, quota } \\
\text { allocations, tax rules) is required. }\end{array}$ \\
\hline $\begin{array}{l}\text { 3. The risk of uncontrolled } \\
\text { biogas production process }\end{array}$ & $\begin{array}{l}\text { The likelihood of the pathogenic bacteria formation due to the lack of proper control } \\
\text { should be minimized by strengthening the control function of the environmental and tax } \\
\text { authorities. }\end{array}$ \\
\hline $\begin{array}{l}\text { 4. Additional costs for the } \\
\text { biomass transportation to the } \\
\text { compost plants }\end{array}$ & $\begin{array}{l}\text { This risk is neutralized by the optimal logistics and rational placement of the processing } \\
\text { plants (compost plants), considering the long-term biomass reserves. }\end{array}$ \\
\hline
\end{tabular}


Table 5. Example of the alternative power engineering option assessment.

\begin{tabular}{|c|c|c|c|c|c|}
\hline \multirow{2}{*}{ Risk } & \multirow{2}{*}{$\begin{array}{c}\text { Specific } \\
\text { gravity }\end{array}$} & \multicolumn{3}{|c|}{ Options of alternative power engineering } \\
\cline { 3 - 6 } & & Solar energy & Wind energy & Tidal power plant & $\begin{array}{c}\text { Biomass power } \\
\text { plant }\end{array}$ \\
\hline $\begin{array}{c}\text { 1. Instability of the power } \\
\text { source }\end{array}$ & 25 & 1 & 1 & 0 & 0.25 \\
\hline $\begin{array}{c}\text { 2. The need for land } \\
\text { allocation }\end{array}$ & 10 & 1 & 0.75 & 0.25 & 0 \\
\hline $\begin{array}{c}\text { 3. Significant capital } \\
\text { investments in the structures }\end{array}$ & 20 & 1 & 1 & 1 & 0 \\
\hline $\begin{array}{c}\text { 4. Climatic and natural risks } \\
\text { (for the source) }\end{array}$ & 20 & 0.75 & 0.75 & 0.5 & 0.75 \\
\hline $\begin{array}{c}\text { 5. Environmental risks (from } \\
\text { the source) }\end{array}$ & 25 & 0 & 0 & 0.75 & 45 \\
\hline TOTAL & 100 & 70 & 67.5 & 51.25 & 0 \\
\hline
\end{tabular}

the specific gravity. The assessment of options is performed on the basis of the following scale: 0 impossible risk; 0.25 - low risk; 0.5 - medium risk; 0.75 moderate risk; 1 - extreme risk.

The aggregated risk estimate [15] of each option is calculated as the product of the risk specific gravity by its probability estimate.

For example, the risk assessment of solar energy $=$ $25 * 1+10 * 1+20 * 1+10 * 0.75+25 * 0=70$.

This example certainly provides a general concept that requires additional data analysis. However, this approach may well be considered for the blitz risk assessment.

Thus, the substantiation of the managerial decision for selection or transition to the alternative power engineering is provided on the basis of the preliminary diagnostics results, considering the current shortage rate of the electric energy generation and transmission, territorial specifications, and financial capabilities of all participants in the energy market. It should be noted that the key decisions relating to the alternative power engineering supply will be made at the regional and national level. However, it is important to note another global risk of transition to the alternative power engineering that is the risk of opportunism [16]. While the main players in the traditional energy market (oil, gas, coal) do not reorient their business towards the alternative power engineering, the development of these areas will be artificially blocked.

\section{References}

[1] J. Yan, F.-M. Tseng, L.-Y. Lu, Developmental trajectories of new energy vehicle research in economic management: Main path analysis Technological forecasting and social change 137, 168-81 (2018)

[2] L. Reichenberg, F. Hedenus, M. Odenberger, F. Johnsson, Tailoring large-scale electricity production from variable renewable energy sources to accommodate baseload generation in Europe Renewable energy 129, 334-46 (2018)

[3] E. Heylen, G. Deconinck, D. Van Hertem, Review and classification of reliability indicators for power systems with a high share of renewable energy sources Renewable \& sustainable energy reviews 97, 554-68 (2018)

[4] G. Gersema, D. Wozabal, Risk-optimized pooling of intermittent renewable energy sources Journal of banking \& finance 95, 217-30 (2018)

[5] E. Togashi, Risk analysis of energy efficiency investments in buildings using the Monte Carlo method Journal of building performance simulation 12(4), 50422 (2019)

[6] J.P. Xie, Z. Li, Y. Xia, L. Ling, W.S. Zhang, 2017 Optimizing capacity investment on renewable energy source supply chain Computers \& industrial engineering 107, 57-73

[7] A. Zafra-Cabeza, P. Velarde, J.M. Maestre, Multicriteria optimal operation of a microgrid considering risk analysis, renewable resources, and model predictive control Optimal control applications \& methods (2019)

[8] M. Hain, H. Schermeyer, M. Uhrig-Homburg, W. Fichtner, Managing renewable energy production risk Journal of banking \& finance 97, 1-19 (2018)

[9] H.W. Pandey, K.R. Gadham, T. Ghose, Risk based Benefit analysis of RES aggregator in Restructured Energy Market 2ND international conference on power, energy and environment: towards smart technology (Shillong, India) (2018)

[10] N. Gatzert, T. Kosub, Risks and risk management of renewable energy projects: The case of onshore and offshore wind parks Renewable \& sustainable energy reviews 60, 982-998 (2016)

[11] C.V. Mikellidou, L.M. Shakou, G. Boustras, C. Dimopoulos, Energy critical infrastructures at risk from climate change: A state of the art review Safety science 110, 110-20 (2018)

[12] J.R. Ribas, M.E. Arce, F.A. Sohler, A. SuarezGarcia, Multi-criteria risk assessment: Case study of a large hydroelectric project Journal of cleaner production 227, 237-47 (2019)

[13] E.N. Manolis, T.D. Zagas, G.K. Karetsos, C.A. Poravou, Ecological restrictions in forest biomass extraction for a sustainable renewable Energyproduction renewable \& sustainable energy reviews 110, 290-97 (2019) 
[14] I. Jonek-Kowalska, Efficiency of Enterprise Risk Management (ERM) systems. Comparative analysis in the fuel sector energy sector on the basis of CentralEuropean companies listed on the Warsaw Stock Exchange Resources policy 62, 405-15 (2019)

[15] E. Giambona, J.R. Graham, C.R. Harvey, G.M. Bodnar, The Theory and Practice of Corporate Risk Management: Evidence from the Field Financial management 47(4), 783-832 (2018)

[16] N. Gatzert, T. Kosub, Determinants of policy risks of renewable energy investments International journal of energy sector management 11(1), 28-45 (2017) 